CATALAN REVIEW

Catalan Review

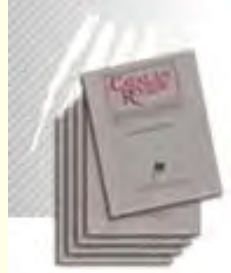

You are accessing the Digital Archive of the Catalan Review Journal.

By accessing and/or using this Digital Archive, you accept and agree to abide by the Terms and Conditions of Use available at http://www.nacs-

catalanstudies.org/catalan_review.html

Catalan Review is the premier international scholarly journal devoted to all aspects of Catalan culture. By Catalan culture is understood all manifestations of intellectual and artistic life produced in the Catalan language or in the geographical areas where Catalan is spoken. Catalan Review has been in publication since 1986 .
NORTH

AMERICAN

CATALAN

SOCIETY
Esteu accedint a l'Arxiu Digital del Catalan Review

A l' accedir i / o utilitzar aquest Arxiu Digital, vostè accepta i es compromet a complir els termes i condicions d'ús disponibles a http://www.nacs-

catalanstudies.org/catalan_review.html

Catalan Review és la primera revista internacional dedicada a tots els aspectes de la cultura catalana. Per la cultura catalana s'entén totes les manifestacions de la vida intel lectual i artística produïda en llengua catalana o en les zones geogràfiques on es parla català. Catalan Review es publica des de 1986.

\title{
From Knight Errant to Ethical Hero to Flatfoot: The Development of the Detective in Catalan Fiction Patricia Hart
}

Catalan Review, Vol. III, number 2 (1989), p. 71-93 


\title{
FROM KNIGHT ERRANT TO ETHICAL HERO TO FLATFOOT: THE DEVELOPMENT OF THE DETECTIVE IN CATALAN FICTION
}

\author{
PATRICIA HART
}

If the term "roman noir" refers to a novel in which the dark underside of human nature is exposed, often accompanied by murder, especially the murder of a defenseless member of an underpriveleged class of society, then I think a good case can be made that the novel.la negra in Catalan has roots as far back as Joanot Martorell's fifteenth-century masterpiece, the Tirant lo Blanc. There, the death of the black gardener, Lauseta, is the result of the evil machinations of the scheming "Viuda Reposada", and the author of the crime remains a mystery to most of the characters in the story for the next twelve chapters, as there were no witnesses. However, the crime poses no mystery to the reader, who knows from the start that the murderer is none other than the hero, Tirant, who has been duped into killing the poor gardener because he mistakenly believes the man has taken liberties with his beloved Carmesina. When the truth is told to Tirant by Plaerdemavida, Tirant wastes no time regretting the death of the Moor, but instead simply vows to kill the "Viuda Reposada" as well when he gets the chance. Tirant's no-nonsense morality, his quickness to act, and this involvement in an ugly crime of passion far from the battlefield or knightly contest all prefigure the roman noir. The novel of chivalry and the detective novel are both popular forms with often stereotypical representations of good and evil, and what is more, the societal conditions that gave rise to chivalric fiction and those that prompted the recent boom in Catalan detective novels have some interesting parallels.

For example, in around 1275 when Ramon Llull sat down to pen a description of the disorder in Mallorcan society and the 
world at large that necessitated the creation of a chivalric order, he said, "Defallí, caritat, lleialtat, justícia e varitat en lo món. Començà enemistat, deslleialtat, injúria e falsetat” (4I). As a solution to these ills, Llull envisioned an association of Christian knights, who through their nobility, charity, strength, prudence, sense of justice, and fear of God would overcome the evil of the world and create a feudal paradise.

Some seven hundred years later, within the geographical boundaries of the Franquist Spanish state, Llull's plaintive cry for justice, truth and loyalty was unfortunately still as timely as when he wrote it. However, at that point, although appreciation for the cultural safekeeping bravely carried out at the Monastery of Montserrat was deep and sincere, opponents of social injustice in Catalunya were far from agreeing on a Christian utopian model as the solution. So when it came to making fictional beings to fit the times, it is no surprise that a Christian knight like Tirant was no longer possible. Instead, one of the most interesting fictional types to emerge in late Franquist and post Franquist Catalan fiction is the lonely, alienated figure of the down-at-the-heels detective.

The distance from Knight Errant to detective is not so great as my breathtaking leap over seven centuries of Catalan literature might lead one to suspect. The Knight Errant, after all, is both an intellectual and a popular response to societal injustice, a larger than life figure of a moral hero who sets society to rights when men have swerved it from its proper course. Likewise, as W. H. Auden pointed out in his essay, "The Guilty Vicarage", the detective who first emerges from Poe's "Murders in the Rue Morgue" is a force of reason against evil, an ethical hero who by his superior force, now largely of intellect, also sets out to right wrongs. Think of the early classic detectives - Auguste Dupin, Sherlock Holmes, Father Brown, Hercule Poirot, Miss Marple, Lord Peter Wimsey, Nick and Nora Charles, Judge Dee, Perry Masson - they are all forces for right in a cosmos muddied by crime, and through their actions the universe is once 
more, if only temporarily, set right. With the advent of the roman noir, however, the detective is no longer clearly a hero, and although he is up against crime and corrupt society, he is no longer always able to set the universe straight, and in fact, often the best he can do in a given case is simply survive it. The classic example of this kind of sleuth is, of course, Chandler's Philip Marlowe, a man who like Conrad's Marlow, his literary namesake, ventures into the heart of darkness and comes back shaken and scarred, but wiser. The detective from the Chandlerian mode seeks knowledge, but often cannot right the wrongs he uncovers, and must content himself with understanding and living through them.

Detective fiction has been widely read in Catalunya, and just as in the English-speaking world, early on had intellectual supporters. Those who remember W. H. Auden's enthusiasm will not, then, be surprised to discover that the great modern Catalan poet, Josep Carner, was also an avid reader of the genre, who claimed at many periods of his life to have consumed at least one detective novel a day, and who also thought that what he called, «literatura de lladres i serenos" was «el gènere literari més ben pagat del món".I

Since the detective in Catalan fiction emerges relatively late as compared to English or American traditions, although substantially earlier than in Castilian-speaking Spain ${ }^{2}$ the stereotypes of the genre are already firmly in place. For this reason, I would like to look at several key examples of Catalan fictional detectives and try to characterize them to see of they are ethical heroes, knights errant, or damsels in distress, archetypal figures with their roots in the Catalan tongue's earliest classics, or simply parodies or carbon copies of English-speaking models.

Closest to the last are the earliest attempts at detective no-

1. Quoted in Rafael Tasis i Marca's prologue to Un crim al Paralelo, p. 9.

2 See the Chapter titled "The Catalan Connection", in Hart, The Spanish Sleuth. 
vels in Catalan. C. A. Jordana and Antoni Careta i Vidal both published detective works without receiving much attention. 3 More successful was pionner and catalyst Rafael Tasis i Marca, who was exiled from Catalunya in 1939 at the end of the Civil War, and returned in 1948, full of impressions from his readings and translations (largely from English) of foreign masters of the genre, and anxious to encourage production in Catalan.

Of his three detective works - La Biblia valenciana (1955), És hora de plegar (1956), and Un crim al Paralelo (composed in 1944, but first published in 1960) - the last is in many ways the most interesting. The novel stars journalist Francesc Caldes of Terrassa and police inspector Jaume Vilagut of the Drassanes port district of Barcelona, and tells of a vendor of lottery tickets found strangled in her apartment near the Paral.lel in 1934.

But though setting and character are supremely Catalan, the novel constantly underscores the essential artificiality of the genre, and a foreign artificiality at that. Journalist Caldes states his desire to write a supreme "tractat sobre la novel.la policíaca" (38), 4 and he constantly sprinkles the tale with references to foreign authors like Poe, Sayers, Hammett, Van Dine, Conan Doyle, Leblanc, Simenon, Christie and others. Even the more "literary" references are foreign, not domestic. Caldes calls the young Valencian suspect in the murder a "Raskòlnikov de via estreta", then says to himself:

Si no és un personatge de Dostoievski, que sigui almenys de Blasco Ibáñez. Ho desitjo de tot cor. (78).

Apart from a passing reference to Luis de Val ( 152 ), not a single other one of many literary references and allusions is to an author from the Iberian Peninsula, let alone to a Catalan writer. This is understandable, for as Tasis explains in his prologue, de-

3 Tasis prologue, to.

4 A desire shared by Tasis himself. See his prologue, to. 
tective fiction was considered a "gènere menor" in Catalunya and that therefore Catalan readers "han d'anar a cercar en altres literatures allò que no els dóna la pròpia” (ro).

The structure of the story is full of conventions a la Agatha Christie, like the final chapter, titled, "Reunió general", in which the two sleuths get all the suspects together in the cabaret «Moulin de la Joiem,s (conveniently empty for Good Friday) reconstruct the crime, accuse the correct person, extract his confession, face him down a gun barrel, and then finally see to his arrest. There is a sense of too much attention being paid to setting up these conventional scenes, and not enough to following the logical solution of the crime. The murder has in fact revealed himself in a particularly hackneyed way nearly seventy pages before the dramatic conclusion. When the sleuths confront him and say "Sap que el senyor Josep Jordà, el seu client assidu, ha estat trobat assassinat aquest matí?» (179), the suspect answers: "Estic consternat del que em diu. El senyor Pepet: Un home $\tan$ agradable, $\tan$ ben educat! Se sap qui l'ha apunyalat, i per què?" (I79)

The suspect pretends to be surprised at this news, and behaves as if he were just learning it, yet knows without being told that the victim was stabbed. This gaffe by the suspect is especially obvious, as the previous victim was strangled, not stabbed. Yet neither of the detectives notices. The average mystery reader is likely to notice at once, and to identify the suspect as the killer, with nearly a third of the novel (full of some fairly tedious detecting) still to go. A fan of detective fiction expects the sleuths to at least "remember" this slip-up later, and to mention it in the "reunio general", but in fact no mention of it is made. It is as if Tasis either forgot the planted detail, or decided at the end to discard it in favor of others equally derivative of the authors Caldes loves to cite.

Still, all of this is not to say that the book is not Catalan.

5 A clear reference to the Paral.lel's notorious "Molino". 
Apart from references to "el third degree" (99) and so on, the language is delightfully local, with no compunctions about portraying a Catalan tongue that lives side wide Castilian. Said Tasis himself of the language:

És volgudament acostat al que és propi en els llocs de l'acció. Ja es comprèn que les meves concessions no arriben al català absolutament depauperat que s'hi sent a cada cantonada; pero m'ha semblat que $\mathrm{Pa}$ ralelo lligaria més que Paral-lel, i moneder més que portamonedes. (I4-I5)

The descriptions of the barri xines are also inspired, evoking well the sad glory of prewar cabarets where a would-be ballerina fails with the audience for trying to perform a classical dance when she could have triumphed with "una jota qualsevol, o un zapateado sense compromís" (I59); where the cupletistas also perform striptease, and where the public flocks to «revistes de gran espectacle, on el nu femeni, el facil lirisme i la comicitat vulgar es barrejaven en dosis científiques" (60).

On the level of sexual politics, the book is extremely interesting. The victim, Maria Bardaji, was in her sixties, but had a "protege", Josep Ballester, in his twenties, who is suspected of her murder. Indeed, the book invites us to sympathize with young Josep, and to think he would have been justified in strangling her to rid himself of her nefarious "desigs senils" (233). Likewise young Pere Duran falls into trouble with the law and loan sharks because of his involvement with older and more experienced Lluissa Solans. At the same time, both newsman Caldes and cop Vilagut are still living at home with their admiring mothers, something difficult to imagine Sam Spade or Philip Marlowe ever doing, if indeed they even had mothers. Perhaps this unintentionally Freudian presentation of both detectives and detected as latent or blatent Mama's boys is in the end most Catalan - a phenomenon of economic reality in the 30 's when few men could afford bachelor pads, and most moved away from their mothers only when they married. The book reflects both 
this reality and also the resentment such a situation must have sometimes entailed. The unfortunate stereotypes about older women in the book underscore the difficulty both sons and mothers must have sometimes had in gaining independence from each other. According to the morality of the book, "good" older women behave like the mothers of the two detectives, providing cooing, unquestioning admiration and good hot food whenever their sons drop by that hotel called home; "bad" older women are those who live on their own, support themselves and perhaps their lovers as well, defy convention, and want independence. Both Lluîsa and Maria have their own apartments and greater economic freedom than any of the men in the book - a freedom earned in both cases by exploiting the weaknesses of men. Even old Pepet is in debt to Maria, and while he is seen admirably as not wanting to be a burden on his children, Maria, by contrast, is described as being full of "avarícia senil" (235). One suspects that the adjective "senil" would hardly have been applied so freely to a man of corresponding age who simply wanted plenty of money and a younger lover. Offhand, one suspects he would be more likely categorized as "normal".

Taken altogether, then, although the book superficially appears to be a copy of foreign patterns, on a deeper level, language, character, and setting are authentically Catalan. Sexual politics reflect the time of the books setting (1934) as much as the author's individual views, and at the same time serve to distinguish the book from Anglo-Saxon models.

Tasis proclaimed that part of his motivation in writing detective fiction was "el desig que altres escriptors catalans volguessin engrescar-se a escriure també llibres d'aquesta mena» $(\mathrm{Crim}, \mathrm{10})$. In this his success was more complete as he served as a catalyst for his good friend and fellow translator of foreign detective novels into Catalan in the Cua de Palla series: Manuel de Pedrolo.

In 1953, fifteen long years before Francisco García Pavón won the Premio de la Crítica for El reinado de Witiza, a detective 
novel written in Spanish and set in La Mancha, multifaceted writer Manuel de Pedrolo ventured into the detective genre with L'inspector fa tard, the story of a bank worker who sees his chance to make it rich when the bank is robbed one day, only to find himself in competition with the robbers themselves, as well as the police. In 1958 he published Es vessa una sang facil, a dark depiction of murder, but publishing being what it was in the fifties, it is not surprising that neither of these books was ever translated into Castilian. Following these, and in addition to his other writing, Pedrolo published four other books which Salvador Vázquez de Parga classifies as novela criminal: Joc brut (1965), Mossegar-se la cua (1968), Pas de ratlla (1972), and Algú que no bi havia de ser (1974). Nevertheless, Pedrolo wrote to me in a personal letter in 1983 that he himself only considers L'inspector fa tard, Joc brut and Mossegar-se la cua as detective works.

I will concentrate on what I consider to be Pedrolo's crime masterpiece, Joc brut. I see Xavier Rius, the protagonist of Joc brut, as a knight errant born into the wrong century. Growing up without a father near at hand was no insurmountable problem to a medieval knight, so long as an accomodating hermit could be found to instruct him in the ways of chivalry, but for Pedrolo's Xavier, the fact that his father was killed as a Republican soldier in the Civil War was the first in a series of disastrous events that determined his destiny. Xavier himself describes it:

La mare $\mathrm{i}$ jo vam venir /a Barcelona/ en acabar-se la guerra que va deixar-la vídua, perquè el meu pare havia mort al front, al costat dels vençuts, i mai no havíem rebut cap ajuda. Ella feia feines per las cases, vetllava malalts, jo havia treballat de grum en una oficina, de corredor d'articles electrodomèstics... Vaig brandar enèrgicament el cap... per tal d'allunyar un pensament encara més coent: el record d'un pis que hauria pogut ser nostre, perquè la mare havia anat recollint com una formiga fins a reunir les vint mil pessetes que calia pagar d'entrada, quan la casa encara no havia estat començada. Ni va construir-se mai del tot; no passà dels fonaments. L'empresari va fer-se fonedís amb els diners... (I5-16) 
One can see, then, in Xavier Rius a man with the spirit of a Knight Errant forced by circumstances into living an existence that more closely resembles the picaresque, as a servant of many masters, a desperately poor young man orphaned early, to whom hunger is no stranger. Nevertheless, when Rius falls in love, he is every bit as courtly and devoted to his lady fair as ever a knight was. What is more, Pedrolo's treatment of sexual tension between Xavier and his beloved Juna is more than a little reminiscent of classic scenes of frustration created by Joanot Martorell in the Tirant. Who can forget the way Plaerdemavia maneuvers Tirant into bed with Carmesina? The following sexual power struggle occurs. Says Tirant:

Senyora, molt me tarda vos ves en camisa o tota nua en llo llit. Jo no vull vostra corona ni la senyoria d'aquella; dau-me tots mos drets a mi pertanyents segons mana la santa mare Església dient semblants paraules: «Si les donzelles ab treball són ajustades a matrimoni verdader, qui pot e no ho fa, peca mortalment si lo matrimoni no s'hi segueix còpula..." (Vol. II, II8)

To this Carmesina replies:

$\mathrm{Ab}$ ma tremolant eixugaré los meus trists ulls ans que res te diga. iOh quantes piadoses paraules t'he ofert e no et plau acceptar-les!... Placia't senyor Tirant, no em vulles donar causa d'ira e d'aborrir-te, car grandíssima virtut és resistir a les males inclinacions de delit. (ח, 1 I9)

Carmesina avoids consumation from a pratical fear of pregnancy and discovery, and perhaps also, as the Tirant's English translator David H. Rosenthal suggests, from an adolescent fear of the act itself. Nonetheless, she has no compunctions about keeping Tirant at a level of sexual excitement for hours on end, once she is sure she can control him, and the lovers spend the rest of the night, «jugant e solaçant, adés al cap de llit» (II, $\Pi 9$ ).

The exchange between Xavier and Juna is similar. After a wrestling match witch Xavier has lost, he finally explodes, «No 
està bé, Juna - vaig queixar-me un cop -. Això és brut» (23). Like Tirant, since he is in love with his lady and offers marriage, not consumating the relationship seems a sin. But like Tirant, he is still enough of a gentleman at this point to be moved by his love's tears.

" - No, Xavier... si et plau, si et plau... Era una queixa ininterrompuda $\mathrm{i}$ no podia ignorarla tot i la urgència insostenible del meu desig." (38)

To reveal the surprises of the plot here would definitely be a «joc brut" on readers who have not yet read the book, so I will simply conclude my characterization of Xavier Rius as a Knight Errant born into the wrong time by saying that like Tirant he is idealistically devoted to his lady, like Tirant he tries to rise above his station to win the lady's affection, and just as Tirant is deceived into killing Lauseta out of his love for Carmesina, Xavier Rius is manipulated into murder by his love for Juna. Ultimately both find death at the end of their attempts to do the right thing. Xavier's inheritance from the Catalan picaresque tradition is also evident in his struggle against poverty, his service to many heartless masters, and even in his deception, for some 550 years before Xavier's trials began, the protagonist of Jaume Roig's Lo Spill encounters a woman of similarly evil intentions, the wife of the Valencian bandoler who tries to make him commit murder. With these references to monuments of the Catalan literary tradition, I am not trying anything so dangerous as proving direct influences on Pedrolo, but rather simply to show up as too simplistic the conventional wisdom that holds that Pedrolo's detective fiction mirrors his translations from hard-boiled giants in his Cua de Palla series, and that whatever he takes from a foreign from he makes firts decidedly Catalan, and then indubitably his own.

Joc brut was translated into Castilian in 1972 by a young admirer of Pedrolo who published that same year his own first novelistic attempt on the genre with De mica en mica, s'omple la 
pica, Barcelonan Jaume Fuster. Fuster is the first to admit his debt to the American detective, and the book is dedicated in part to the likes of Philip Marlowe and Sam Spade. But he also recognizes Rafael Tasis and Manuel de Pedrolo, "que varen tenir la gosadia d'escriure novel.les policíaques en català».

On first glance, Enric Vidal, the protagonist of De mica en mica..., seems to be a character as far removed from Llull's ideal Christian knigth as can be imagined. But is he really? On the surface, Enric is a fairly typical product of postwar cynicism and the force of economic despair. At the beginning of the novel, Enric has been expelled from Pharmacy studies in the University for misdeeds explained in full in the short story, "Ofelia a les tres", published in the Ofelia Dracs collective work, Negra $i$ consentida, in 1985 . Enric is an expert at taking advantage of women. Not above cadging money from his sister, Enric then scrounges work from the married man who is keeping her, smuggling money across several borders. From there, he moves to blackmail and a variety of other legal infractions large and small, but as he gradually realizes who pulls the strings in this puppet show, Enric eventually reveals that he does have a conscience, albeit a deeply buried one. The death of his sister, combined with his encounters with Pere, a coveralled labor organizer who reminds Enric of his father, practically convice him that he can stand alone against a corrupt system, side with the downtrodden laborer, and come out ahead. We remember now that in "Ofelia a les tres" when searching for a convenient explanation for his expulsion, Enric pretended that he had been kicked out for participating in a student demonstration. At the climax of De mica en mica..., it is as if Enric tries to convert these lies and fantasies into reality. We read:

«El record del pare, de les paraules del pare, es feien vives al meu cap. Els podia ajudar $i$ els ajudaria; i tant que els ajudaria!n (I42)

At this point Enric has visions of riding to the rescue of the workers, a knight in shining armor, but the illusion soon tar- 
nishes, and Enric realizes once more that if every man has his price, his own is embarrassingly low.

In his subsequent novel.les negres, Tarda sessió contínua (1976) and La corona valenciana (1982) in which Enric Vidal reappears, Fuster continues to exploit the notion that a lone hero (ethical or otherwise) can never succeed in solving collective problems. He told me in an interview conducted in $\mathrm{I}_{98}{ }_{3}$ in Spanish:

Enric Vidal quiere solucionar el problema de los trabajadores él solo. Marlon Brando lo hace. Enric Vidal no. ¿Por qué no? Porque yo creo que nunca un individuo ha resuelto el problema de la colectividad. Siempre ha sido la colectividad que lo ha resuelto. (Hart, The Spanish Sleuth, 82)

Once more, then, studying the main character of a new Catalan detective novel reveals it to be clearly different from a North American model. As Fuster himself pointed out:

La diferencia de tratamiento entonces es una diferencia entre Norteamérica y Europa. El americano es básicamente individualista. /Y sin embargo tiene éxito./ Esto es falso. Lo que ha pasado de verdad es que los obreros se han reunido, han hecho huelga, y han perdido muchas veces y ganado algunas... Enric Vidal se vende, y Bogart en Tarda sessió contínua acaba vendiéndose porque el individuo se vende. (Hart, 82-3)

In a different vein, Fuster produced the drama Les cartes d'Hèrcules Poirot in 1983, a congenial parody of what Hanna Charney calls "the detective novel of manners". Working within a standard "enigma" plot of the kind Agatha Christie favored, Fuster produces a delightful sendup of the detective as ethical hero and bourgeois righter of wrongs, all in a supposedly "littleknown" case that occurred when the master visited a Catalan spa during the postwar. Once again, Fuster makes the genre uniquely Catalan, and of course his solution involves the triumph of seny over Poirot's little grey cells, as the Belgain must be led 
to the solution by a sort of Catalan Miss Marple, the redoubtable senyoreta Puig.

The most light-hearted and ludic of all Fuster's detective fiction are his short puzzle pieces, first published in a continuing column, Les claus de vidre, ${ }^{6}$ in the magazine El Món, and then collected in a book with the same title. Each of the seventeen stories in the collection presents a short mystery resolved by Barcelonan detective, Lluís Arquer (a tribute to Ross MacDonald's Lew Archer). At the end of the book there is a brief explanation of the way Arquer arrived at his brilliant conclusions, but before turning to it, the reader has the chance to match wits with the detective and suggest his own explanation. These delightful stories function perfectly well as mysteries and effortless escape reading, but at the same time give a run-down on Barcelona society from top to bottom, collect Catalan sayings, comment on local foibles, and even provide linguistic insight into the differences between a Cerdanya and a Barcelona accent. His ten page "El rapte de les sabines" shows a decidedly more clever use of the allusion than García Pavón made in an entire novel; "Assegurança de vida" rings with double meaning: "Fiat Lux", "Març marçot, mata la vella i la jove si pot", and "No dispareu contra el burgès" are all as much fun as their titles imply. Once more, Fuster proves that although a spark of inspiration came from a foreign source, he knows how to synthesize inspiration with experience to make the whole decidedly his own.

Upon arrival at the next detective on the list, we find that the idea of the detective as knight in shining armor is once more pertinent. His creator is Majorcan Antoni Serra, his theater of detection is the world, and his name is Celso Mosqueiro. In the second of the three Mosqueiro novels to date, L'arqueologa va somriure abans de morir, we discover that in fact the halfPortuguese sleuth even has a basset hound named Tirant, called

${ }^{6}$ An obvious hommage to Dashiell Hammett's The Glass Key. 
after Martorell's knightly hero. In the third novel of the series, when a prospective client climbs aboard Mosqueiro's houseboat to find the dog barking excitedly she asks if he bites, and Mosqueiro answers ironically, "esper que no, perquè és un cavaller" (II). But it is evident from the beginning of the series that the functions of knight errant must be split between man and dog, with dog retaining the more noble part, as the cold realities Mosquerio faces in his investigation do not allow him to practice chivalry routinely, even though he sometimes longs to. In his third adventure, for example, he walks a beach late at night waiting to resolve a case the following day, and imagines a scene from chivalric lore: "Es digué que havia passat la prova a l'estil del cavallers antics que vetllaven les armes" (Espurnes de sang, 19I-192). But as soon as he thinks this, his practical sense interferes and forces him to re-evaluate cynically:

Immediatament d'haver-ho pensat, trobà que era una xorrada impròpia d'una ment sana, de manera que se'n rigué i tot, "tal volta sí, que me n'hauria d'haver anat a dormir a l'hotel", rumiejà com per dissimular l'estirabot de cavalleria amb què s'havia obsequiat. (192)

For Mosqueiro, as for Fuster's Enric Vidal, the world of investigations is a corrupt place where justice rarely prevails and the rich, like the old nazis in El blau pal.lid de la rosa de paper or financier Maldà in Espurnes de sang, routinely escape punishment, while lesser criminals tangle with an ineffectual police force. In this way, both Fuster's and Serra's mysteries are classic examples of what Italian critic Stefano Tani calls in his book, The Doomed Detective, innovative anti-detective fiction. Tani defines this as fiction that renews and at the same time undermines the traditional detective novel by stressing social criticism, solutions in which justice does not prevail, and the detective's inability to maintain detachment.7

7 Tani cites as examples of innovative anti-detective fiction $A$ ciascuno il suo, by Leonardo Sciascia, The Stunlight Dialogues, by John Gardner, and Il nome della rosa, by Umberto Eco. 
But while Serra's basic plot structures may be said to fit loosely within Tani's category of innovative anti-detective fiction, there is one way in which they are unique, even among the $\mathrm{Ca}$ talan authors discussed in this study. This uniqueness lies in a very personal treatment of and attitude toward the language of the novels' composition.

That detective novels have been written in Catalan at all attests to desire to preserve and strengthen the tongue, as everyone from Tasis to Pedrolo to Fuster has freely admitted. But the approach of Toni Serra goes one step further, showing an endearing relationship to his native Majorca that is distinct from any of the others. To understand how this relationship works I wold like to make a comparison between Mosqueiro and detective-spy James Bond.

Ian Fleming's James Bond was a man of impossible virtues - a photographic memory, technical skills, and considerable prowess not only in love but also in language. Nothing was more common in the series than for Bond to be sent to an exotic locale where he immediately spoke the language (whatever it might have been) fluently enough to pass for a native. When his adventures were translated to the screen, English-speaking viewers saw this represented by the device of having dwellers of foreign lands speak to Bond in accented English. Indeed, a child who watched Bond represent Her Majesty's interests abroad might have concluded that the entire world spoke English, with simple variations of pronunciation. Since English was the tongue of the once-mighty British Empire, and of the U.S. of the Cold War where the films earned the most money, the device was considered acceptable, and rarely questioned or even mentioned by English-speaking critics.

What Toni Serra does in his three Celso Mosqueiro novels is to turn this device upside down for the purpose of parody. In El blau pal.lid de la rosa de paper (1985), we are introduced to detective Celso Mosqueiro, who is presented to us as a Portuguese native policeman who is called in to help the Majorcan 
police solve a murder with international implications. Serra makes no attempt at all to explain Mosquerio's fluency in the language of the island, rather simply presents him directly meeting his Majorcan counterpart with a cordial, emolt de gust. Som Celso Mosqueiron (10). A wealth of information is conveyed in the phrase. Not only does the author show by this that he considers it absolutely natural for the language of the island to be spoken by all and sundry (just as Cubby Broccoli's various avatars of Bond find English natural), moreover, he shows Mosqueiro speaking in Majorcan, not Catalan standardized in the Principat by having him say som instead of sóc. Throughout the novels, Mosqueiro's speech is consistently in Majorcan-he calls girls wal.lotes", stops to "xerrar" with witnesses, and conjugates all verbs in Majorcan (supos) instead of suposo, for example), and this refusal to write in what Barcelonans may consider "standard" Catalan reinforces Serra's thesis that Majorcan is a language to be used with no apologies or explanations.

The relation between Majorcan and other languages is also interesting. Some reviewers have commented, thinking to point out a flaw, that when Serra inserts words in English or German, they are almost invariably misspelled, and that names of Germanic places and people are highly improbable. After reading the three books, I am convinced that Serra did this deliberately to prove a point about attitudes of cultural superiority in German and English tourists who frequent the island, and also about foreign writers who use it as a backdrop with little attempt at accuracy or insight. ${ }^{8}$

For example, George Sand's Un biver à Majorque collects a great number of sweeping generalizations about Majorcan culture, some accurate, and many more that could be argued, yet few critics have called her to task on that point. Likewise, in detective fiction, one rarely reads of people scornfully dismis-

${ }^{8}$ As evidence of this, consider that Serra's treatment of French and Italian names and words is completely different, always srupulously accurate. 
sing Agatha Christie's Hercule Poirot's Christmas on the basis of her ridiculous characterization of the young Pilar. Why, then, is it apparently acceptable to be careless in the treatment of certain languages and cultures, but not others? Serra challenges this assumption.

His portrayal of German characters as all decadent (if not practicing nazis), or his English ones as criminals, sexual deviants, or fools, is less xenophobia than provocation to rethink old stereotypes, a Brechtian use of initial alienation of the reader in order to force him or her to think.

By misspelling Leipzig (as Liepzig, Blau, I42), Händel (as Haëndel, Blau, 93), Lily Marlène (as Lili Marlen, Blau, Ir6), Johann Gutenberg (as Guttemberg, Espurnes, 26), Thomas Mann's Der Zauberber (as Zubenberg, Blau 4I), and Munich's Hofbräuhaus (as Holfbraübus, L'arqueòloga, 6I) he issues a belligerant challenge to the reader to re-evaluate passive submission to cultural imperialism from without.

Like James Bond, Mosquerio moves through a novelistic world where everyone speaks to him on his terms, in his tongue, and where other languages must fend for themselves. In sex, too, Mosqueiro resembles Bond. Just as Bond routinely beds treacherous foreign agents (frequently communists), Mosqueiro triumphs sexually of the German and English women in his path who are his ideological enemies. Like the "chicas Bond", the "al.lotes Mosqueiro" tend to be either dangerous or empty-headed, but all come equipped with "pits bellugadissos". And if Sabeth Peeperkon, Marlen Distracken, Qwerdeen Crack, Moira Peecpack, or Konstanz Koëring seem unlikely names, consider if they are any less likely or more offensive than Fleming's Kissy Suzuki, Pussy Galore, Bambi, Thumper... and so on. As if to reassure the reader in the end that sexual politics of Mosquerio are not his own, Serra pointedly makes abrupt departures from the Bond-like sexual prowess, giving Mosqueiro a gigantic, hideous abscess on his bottom that makes him look like a baboon in Blau, and a hernia in L'arqueologa. In the second 
book, in one ironic scene, Mosqueiro kisses a young woman, and what she thinks is his "member of steel" turns out to be the metallic truss (constructed by sadistic German orthopedists) the detective is wearing in order to continue detecting while ruptured. With details like these, Serra reminds us not to take Mosqueiro and his attitude too seriously.

Although in L'arqueòloga Serra actually added a few words of cursory explanation for Mosqueiro's fluency in Majorcan (his mother was a catalana from the barri de Grácia who required him as a small boy to read Mercè Rodoreda and Joanot Martorell, 3I), still, the series manages to maintain its inversion of the stereotype of linguistic and cultural imperialism, deftly switching Majorca from dominated to dominant (even within the Catalan speaking world). Perhaps the best expression of this comes in Espurnes de sang when Moira Peecpack admits with a complete lack of embarrassment that she has no idea who Josep Pla was, or what "L'Empordà" might be. Mosqueiro's answer, "Tu t'ho perds, petita" (80), underscores Serra's point. Why should he be required to speak of German culture with hushed reverence (and careful orthography) if German visitors to his adoptive home show blithe unconcern towards things Catalan and Majorcan?

Serra is a detective series conscious of its antecedents with ironic references not only to English and American masters (for example, Mosqueiro meets Georges [sic] Smiley in London), but also Spanish contemporaries as well (Mosquerio is also acquainted with Barcelonan, Pepe Carvalho). Serra's spare style and imagistic, Blitzkrieg descriptions (to make an allusion which Mosqueiro would doubtless understand, but stubbornly refuse to spell correctly) all attest to his journalistic training, and most importantly of all, his love for Majorcan lore and tongue is something his native readers can take to heart as a healthy escape valve for accumulated stresses brought on by the beautiful Balearic Islands' economically solvent, but frequently uncouth Germanic visitors.

The last detective I will discuss here is another native of Ma- 
jorca, Maria Antònia Oliver's Lònia Guiu. In order to characterize her, I would first like to return to critic Hanna Charney's notion of the detective novel of manners. For one thing, the novel of manners is an early form in which women's excellence was tolerated. For another, the term goes far toward explaining the popularity of detective fiction today from massmarket readers to critical students of literature. Charney sees the detective novel as a form of noble protest against a certain exhaustion of the narrative impulse she detects in much of modern literature (Manners, XI). For her it is logical that "intellectual" readers should also turn their attention to the form. She says:

The yearning for premodern forms, nostalgia for a society that has disappeared, and a sense of history are not the exclusive province of upopular art”... Until the 1930's the novel itself was seen as a lowly genre. (xI).

Appropriately enough, Maria Antònia Oliver comes to the premodern detective format after writing a series of postmodernform novels to excellent critical response, but with limited popular success. However, Oliver brings her liberated, post-modern consciousness to her two detective works, making them perhaps the furthest from the American hard-boiled tradition of any I have discussed here. One simple reason for this is that Oliver, unlike Fuster and Pedrolo, was never a particular fan of detective fiction of any kind, as she freely admitted to me in an interview last summer.

But another reason for this difference is the feminist core of both books. In the hard-boiled detective story, even more clearly than elsewhere in the novel since its inception, there are traditionally really only a few roles for women characters: femme fatale, hankie-wringing damsel in distress, loyal secretary, witness, or victim, and in the end, most of these appearances register on just two moral extremes: active and evil, or good and helpless. Oliver's relative ignorance of the genre and its convention was 
probably all to the good in helping her break away from phallocentric structures.

Oliver's protagonist, Lònia Guiu, is a Majorcan native who has forged a private detective business for herself in post-Franquist Barcelona assisted by her male sidekick, Quim. Through Lònia, Oliver shows us brilliantly that the problem of creating feminist fiction is nowhere near as easy as just plugging women into the starring roles, for all of the subordinate relationships between detective and bad guy, detective and corrupt businessman, detective and female victim, detective and loyal secretary, involve different sexual politics and even physical risks when the detective is a woman. In Estudi en lila, Oliver charts the difficulty women themselves have in abandoning the role of victim - specifically with regard to rape. It is to her credit that she suggests no easy answers, and instead points out where the extremes lead - the young woman who cannot manage to fight back against societal responses to rape is eventually destroyed, while the woman who does fight becomes a vicious destroyer herself. Lònia is left alone at the end of the novel to ponder whether there may be a middle ground between these extremes.

In Antipodes, the plot centers around prostitution of women, both the traditional sexual brand, and also the kind called domestic service. As the title suggests, the women in Oliver's novels are often islands, isolated from each other and men, and connected only by a sea of exploitation. Once more Lònia shows in the book that being female and a private eye is not a simple inversion of the male role, but actually involves additional dangers. Lònia must not only take physical blows from her opponents the way a Sam Spade or a Lew Archer might, but she takes them on a smaller, weaker frame that sustains permanent damage, as her injured ear shows. Moreover, she also faces the constant, humiliating threat of rape when she deals with the male thugs who are essential to a good crime story. Feminist crime fantasy, like Lourdes Ortiz's 1979 work in Spanish, Picadura mor- 
tal has detective Bárbara Arenas disarm burly bodyguards and ruffians right and left with nothing more than a well-timed $\mathrm{cu}$ lada, but Oliver chooses instead to be realistic, with the result being a story that is less exhilarating but more authentic.

The novel also shows pointed examples of women socialized to undermine other women in a way they might not undermine a man in the same role - once more showing why Lònia must work twice as hard as a male detective to succed. Her relationships to young women victims in both novels are an especially interesting inversion of hard-boiled conventions. In a male detective who helps out a young damsel in distress, his paternalistic concern often masks sexual interest, an interest which is not infrequently rewarded at the case's resolution, when it comes time for the former victim to express gratitude. By contrast, the relentlessly hetero Lònia has no physical attraction to Sebastiana, the rape victim in Estudi or to Cristina, the young girl forced into prostitution in Antípodes. Her desire to help is more altruistic than in her traditional male counterpart. In one instance she fails completely to save the victim, and in the other discovers that she herself has been victimized by the person pity had moved her to help. Even when she tries the time-honored solution favored by male flatfeet; slugging some satisfaction out of her victimizer at the end of Antipodes, the gesture is less gratifying than she had hoped.

Once again, with Lònia Guiu we have seen an entry into the ranks of the Catalan sleuth who is far from being a carbon copy of an Anglo pattern, but rather a home-grown product. This time I have made the case not by showing similarities with Catalan predecessors (although I am sure there are many), but rather by citing obvious differences with classics of the genre whose conventions Oliver may have absorbed second hand, but still with a deadly accuracy at times that enabled her to turn the genre on its often chauvinistic ear. Neither Knight Errant nor damsel in distress, Lònia is nevertheless still a sort of ethical heroine. Her essence is captured by Kathleen McNerney, who 
writes in the prologue to her English translation, "her role... as mediator and problem-solver is most compelling» (no number). With this insight McNerney gets to the heart of what creating non-sexist fiction and indeed a non-sexist world is really all about - that is, moving from a scheme where physical size and strength win through force to a more equitable one where mediation and reason rule. Lònia may owe little to ancestresses like the pubescent Carmesina from Tirant, and although she is similarly lusty and plain-spoken, she is also no sidekick to the male hero like Plaerdemavida, but just what she does grow from is still open to speculation and study. Critics like Linda Gould Levine, Janet Pérez, and Kathleen McNerney, to name a very few, are beginning to look at voices and images of women in Spain and Catalunya, but there is still plenty of more work to be done.

In conclusion, I'd like to return to the question I posed at the beginning, what is a Catalan detective? - a knight errant, a hero, a villain, a loser, a loner, a mama's boy, a liberated woman, or a social outcast? The answer is yes, they are all of these things and more. The authors I mentioned, and many more, from playwright E. Claveguera i Munté to Nicolau Maria Rubio i Tudurí, Andreu Martín, Guillem Fontera, Jaume Cabré, Joaquim Soler, Joaquim Carbó, Joan Rendé, Isidre Grau, Pep Albanell, Josep Lluís Segui, and others on a list that seems to grow daily, have all produced the varied profusion you would expect of a modern language today that has overcome a threat of extinction to prove that it is still alive, kicking, and best of all, growing.

PATRICIA HART

PURDUE UNIVERSITY

\section{BIBLIOGRAPHY}

Auden, W.H. 1948, "The Guilty Vicarage". The Dyer's Hand and Other Essays. New York: Random House. 
Charney, Hanna. 1981. The Detective Novel of Manners. East Brunswick, New Jersey: Fairleign Dickinson University Press.

Fuster, Jaume. 1972. De mica en mica s'omple la pica. Barcelona: Edicions 62.

- 1983. Les cartes d'Hercules Poirot. Barcelona: Edicions 62.

- 1984. Les claus de vidre. Barcelona: La Magrana.

- 1982. La corona valenciana. València: Eliseu Climent.

Hart, Patricia. 1987. The Spanish Sleuth. Cranbury, New Jersey: Fairleigh Dickinson University Press.

Llull, Ramon. 1980. Llibre de l'orde de cavalleria. Barcelona: Edicions 62.

Martorell, Joanot, and Martí Joan de Galba. 1983. Tirant. lo Blanc. Barcelona: Edicions 62.

Olrver, Maria Antònia. 1987. Estudi en Lila. Barcelona: La Magrana. Translated into English - Study in Lilac - by Kathleen McNerney. Seattle: The Seal Press, 1967.

- 1988. Antípodes. Barcelona: La Magrana.

Pedrolo, Manuel de. 1982. Joc brut. Barcelona: Edicions 62.

- 1983. Mossegar-se la cua. Barcelona: Edicions 62.

SAND, George, 1988. Un biver à Majorque. Barcelona: Luis Ripoll Arbós.

SERRA, Antoni. 1986. L'arqueòloga va somriure abans de morir. Barcelona: La Magrana. Moll.

- 1985. El blau pal.lid de la rosa de paper. Palma de Mallorca:

- 1987. Espurnes de sang. Barcelona: La Magrana.

TANI, Stefano. 1984. The Doomed Detective. Carbondale and Edwardsville: Southern Illinois University Press.

TAsis i MarCA, Rafael. 1960-1987. Un crim al Paralelo. València: Eliseu Climent.

VÁzquez DE PARgA, Salvador. 198r. Los mitos de la novela criminal. Barcelona: Planeta. 